\title{
THE SOUTH AFRICAN TRADITIONAL BELIEF SCALE AS AN INSTRUMENT TO AID CUL- TURE-CONGRUENT HEALTH CARE
}

\author{
Johann Beuster \\ D Litt et Phil \\ Principal Lecturer, Department of Psychology, University of Johannesburg \\ Corresponding author: bster-jt@rau.ac.za
}

\author{
Gerhard Schwär \\ D Litt \\ Lecturer, Department of Psychology, University of Johannesburg
}

Key concepts: South African Traditional Belief Scale; cultural beliefs and values; culture-congruent care; culture sensitivity; treatment compliance

\section{SUMMARY}

Medical and psychological health care professionals are becoming increasingly aware that effective treatment in culturally diverse societies requires sensitivity to the patient's cultural beliefs and customs (Davidhizar \& Giger, 2001:2; Foley \& Wurmser, 2004:2; Hickson \& Christie, 1989:162; Mkize, 2003:4; Narayanasamy, 2003:1). To this end this article introduces the South African Traditional Belief Scale (SATBS) as an instrument to enable culturecongruent care, not only in the medical field, but also in psychotherapy and counselling. This scale measures the extent to which black South Africans adhere to traditional beliefs and customs. To obtain reliability and validity data, 64 second-year students were randomly selected at the East Rand campus of Vista University. The reliability of the SATBS was established by calculating inter-item correlations. A reliability coefficient, or index of internal consistency of 0.91 (Cronbach alpha) was obtained after the first iteration. In order to establish criterion validity, the South African Traditional Belief Scale was validated against the Degree of Enculturation Survey (DES) by using the same random sample. A validity coefficient of 0.7899 was obtained which indicates a high index of criterion validity. The questionnaire therefore measures what it purports to assess.

\section{OPSOMMING}

Mediese en sielkundige gesondheidsorgberoepslui word toenemend daarvan bewus dat doeltreffende behandeling in kultureel diverse gemeenskappe sensitiwiteit teenoor die pasiënt se kulturele oortuigings en gebruike vereis (Davidhizar \& Giger, 2001:2; Foley \& Wurmser, 2004:2; Hickson \& Christie, 1989:162; Mkize, 2003:4; Narayanasamy, 2003:1). In dié verband stel hierdie artikel die Suid-Afrikaanse Tradisionele Geloofskaal (SATBS) voor as ' $n$ meetinstrument om kultuurkongruente versorging te bevorder, nie net in die mediese veld nie, maar ook in psigoterapie en sielkundige voorligting. Hierdie skaal meet die mate waarin swart Suid-Afrikaners trou bly aan tradisionele oortuigings en gebruike. Ten einde betroubaarheid- en geldigheidsdata te bekom, is 64 tweedejaarstudente ewekansig geselekteer op die Oosrandse kampus van die Universiteit Vista. Die betroubaarheid van die SATBS is vasgestel deur die berekening van interitemkorrelasies. 'n Betroubaarheidskoëffisiënt, of indeks van interne konsekwentheid van 0.91 (Cronbach alpha) is na die eerste iterasie verkry. Om kriteriumverwante geldigheid vas te stel, is dieselfde steekproef gebuik om die SATBS met ondersoek oor die graad van enkulturasie ("Degree of Enculturation Survey" - DES) te vergelyk. 'n Geldigheidskoëffisiënt van 0.7899 is verkry, wat 'n hoë indeks van kriteriumverwante geldigheid aandui. Die vraelys meet dus wat dit ten doel het om te bepaal. 


\section{INTRODUCTION}

Health care professionals in the medical and psychological fields are becoming increasingly aware that cultural customs and beliefs can significantly impact on the patient's attitudes towards and compliance with treatment procedures. This would imply that effective treatment in a culturally diverse society like South Africa not only calls for a sensitivity to cultural differences, but also requires sufficient knowledge about the patient's cultural belief systems (Davidhizar \& Giger, 2001:2; Foley \& Wurmser, 2004:2; Hickson \& Christie, 1989:162; Mkize, 2003:4; Narayanasamy, 2003:1). In this regard this article introduces the South African Traditional Belief Scale (SATBS) as an instrument to facilitate culture-congruent care in both the medical and psychological fields. The SATBS assesses the extent to which Nguni- and Sotho-speaking South Africans adhere to traditional beliefs and customs.

"Culture-congruent care is described by Leininger as acts and decisions that are tailor-made to fit in with the values, beliefs and ways of life of clients and are certain to lead to service delivery that is meaningful, beneficial and satisfactory to clients" (De Villiers \& Herselman, 2004:23). Culture-congruent care furthermore implies that the practitioner shows sensitivity and respect to individual cultural differences (Foley \& Wurmser, 2004:4). Cultural sensitivity, however, does not imply that the human care universalities should be discounted (Foley \& Wurmser, 2004:2). It merely implies that health interventions in a culturally diverse society should draw not only on universal principles, but should also be adapted to suit the particular belief system of the patient.

\section{THE NEED FOR CULTURE-CONGRUENT CARE}

The patient's views of physical and mental health are informed by cultural beliefs and values (Tjale, 2004:1). The perception of time and space, beliefs about the causation of the disease, the way of communicating symptoms and the acknowledgement (or denial) of pain are all culturally constructed and can impact on treatment and treatment compliance (Benjamin \& Spacek, 2001:4). In this regard health care practices should be adapted in order to accommodate and respect the patient's cultural beliefs and customs (Green-Hernadez,
Quinn, Denman-Vitale, Falkenstern \& Judge-Ellis, 2004:2). Professionals therefore need to take cognisance of the individual's cultural background when explaining an affliction and the proposed treatment modality. In this way patients will accept the therapy more readily. To provide culture-congruent care requires not only that patients are assessed for their cultural background, but also that the caregiver acquires sufficient knowledge about different culturally defined spiritual beliefs and customs (Foley \& Wurmser, 2004:4; GreenHernadez et al. 2004:1; McEwen, 2004:2).

On an ethical level it is furthermore imperative that caregivers provide treatment interventions and consultations that the patient can understand (GreenHernadez et al. 2004:3). In this regard Green-Hernadez et al. (2004:3) state: "Misunderstanding and errors occur when a patient does not understand the treatment prescribed, uses it improperly or, because the treatment does not fit culturally, disregards the plan without the clinician's knowledge. Extremely negative outcomes ranging from physical harm and even death can be the result of cultural incompetence". Communication problems due to cultural differences could furthermore lead to underutilisation of health resources, or to delayed diagnosis and treatment (Green-Hernadez et al. 2004:4). Misunderstanding of the patient's cultural background could furthermore result in premature termination of the therapy (Hickson et al. 1989:163).

One of the core values of post-apartheid South Africa, based on the notion of "ubuntu", is to respect each human being as a dignified individual. This idea "involves sensitivity to needs and wants of others, sharing, and being sympathetic, caring, considerate, patient and kind. It means qualities such as communication, interaction, participation, reciprocation, harmony, a shared world view and co-operation" (Mkize, 2003:6). Culturecongruent care ensures that the spirit of "ubuntu" is practised in the medical and psychological caring professions.

\section{BENEFITS OF CULTURE-CONGRUENT CARE}

Mokhosi and Grieve (2004:315) state that rehabilitation programmes that do not take a patient's cultural belief system into account are not likely to be successful. On the other hand, enquiring about the patient's 
cultural beliefs and customs can improve the quality of health care and would ensure the best treatment outcomes (Culhane-Pera, 2001:1; Foley \& Wurmser, 2004:2).

Wade and Bernstein (1991:9) furthermore found that culture sensitive counselling increases the credibility of the caregiver. The same authors found in an empirical study that clients rate culture-congruent counsellors higher on scales of expertness, empathy and unconditional regard (Ibid:3).

Culture sensitivity ensures that a supportive relationship is established sooner, and also reduces anxiety and suspicion on the part of the patient (Benjamin et al. 2001:3). Listening empathically to patients (which includes understanding a person's cultural beliefs and special cultural context) will increase rapport and trust, which in turn will lead to better treatment compliance and reduce premature treatment dropout (Benjamin et al. 2001:4; Cubria, 2001:1; Narayanasamy, 2003:3; Wade \& Bernstein, 1991:10). Compliance is especially relevant with long-term treatment, as traditional African patients may visit a western-trained professional for immediate relief of symptoms, but may not necessarily commit to a prolonged treatment regime.

Culture-congruent care could also help patients and their families to make existential sense of the affliction. Traditional African people do not merely want their symptoms treated, but also want to know the existential meaning of their condition. They want to know why misfortune or illness happens to them, and need to know who caused it (Herselman, 2004:140). In this regard Mkize (2003:4) states: "The patient therefore does not consider the 'illness' as something to be cured or controlled, but as something that has to be understood and acknowledged. It is no longer a matter of explaining the mechanisms in order to control them, but of understanding significance, a meaning. The question is not how but why things happen". A culturally competent caregiver will therefore not only take mind/body dimensions into account when explaining a condition and the proposed treatment regime, but would also be sensitive to the patient's social and spiritual needs in this regard (Herselman, 2004:140).

\section{APPLYING CULTURE-CONGRUENT CARE}

Culture-congruent care involves cultural negotiation and compromise, which implies not only that treatment is given which is culturally acceptable to the patient, but also that harmless traditional healing practices can be incorporated into the western rehabilitation or treatment plan (Narayanasamy, 2003:4). For example, traditional healing ceremonies encouraging the expression of emotions can help patients and their families to have a cathartic experience, thereby alleviating anxiety and facilitating better acceptance of the affliction. Traditional African healing ceremonies also ensure greater support from family, kin and neighbours, which in turn would contribute to better therapeutic outcomes (Mokhosi et al. 2004:315). Culture-congruent care, on the other hand, could also require the sensitive altering of beliefs that might be harmful to treatment or rehabilitation programmes. This should be done in an empathic way without violating the patient's fundamental belief system (Ibid).

Culture-congruent care can furthermore be used constructively in prevention strategies, as in the case of HIV/AIDS. Traditionally Africans wear charms to protect them from misfortune. If condoms can be endorsed by traditional healers as protective charms, the use might be widely increased amongst traditional people (Van Dyk, 2000 in Maurdant, 2003:22).

When treating patients suffering from HIV/AIDS, doctors and nurses might furthermore acknowledge that ultimately there might be a supernatural cause for the illness, but on an intermediary level it is caused by a virus which is sexually transmitted. Therefore the traditional healer might know where the disease originated, but medical professionals know what it does to the body (Van Dyk, 2000 in Maurdant, 2003:22). The culturecongruent caregiver therefore does not discount the beliefs of the patient, but explains to him or her how western medicine fits into the healing system. In this way health care practices become more palatable to the recipient.

Culture-congruent psychotherapy, on the other hand, might require family or group interventions, because in traditional African culture there is no such thing as an individual problem (Mkize, 2003:4). Extended family and kin should share the responsibility with the client (Hickson et al. 1989:165). 
Hickson et al. (1989:164) furthermore state that older traditional African clients might find non-directive psychotherapy mystifying and would require the therapist 'to behave like a doctor, 'authority', or a 'father figure', thereby taking the initiative and dispensing suggestions and advice".

\section{THE NEED TO ASSESS CULTURAL BACKGROUND TO ENSURE CULTURE- CONGRUENT CARE}

To ensure culture-congruent care, health care professionals need to assess their clients' cultural background in order to understand their beliefs, customs and needs (Davidhizar et al. 2001:2; McEwen, 2004:9). In this regard Culhane-Pera (2001:1) suggests that patients should be interviewed about their cultural background. However, few health care professionals have the time or opportunity to conduct such lengthy interviews. In this regard the authors suggest that the SATBS can be used as an assessment of black patients' cultural context. This self-report inventory consists of 41 items and can be completed in a relatively short time.

The SATBS enables the health care practitioner to assess to what extent Nguni- and Sotho-speaking patients adhere to traditional beliefs and customs. Such traditional African patients would require special culture-congruent caring practices. This implies that western treatments should be presented in a way which is both culturally acceptable and comprehensible to the patient (Examples of such treatment adaptations were given in the section dealing with the application of culture-congruent care). The SATBS can also indicate that participants have incorporated western ideas into their belief system (acculturation) or have lost touch with traditional beliefs and have become entirely westernised (deculturation). Such patients, however, would not require any additional culture-sensitive care, as they would be more likely to accept and understand western treatment practices and would be more willing to comply with the therapeutic procedure.

Having outlined the necessity of culture-congruent care, its benefits and possible applications, and the need for assessment tools in this regard, more detail can be given about the SATBS. The following section will not only describe the technical development, scoring and interpretation of the SATBS, but will also briefly outline how this tool can be used to ensure culture-congruent care. The main aim of this paper, nevertheless, is to introduce the SATBS as an assessment tool to indicate whether patients hold traditional beliefs and customs. Knowing where a patient lies on a cultural continuum could then sensitise the caregiver to apply culture-congruent treatment. The actual detail of such a treatment is, however, beyond the scope of this article.

\section{THE SOUTH AFRICAN TRADITIONAL BE- LIEF SCALE}

\section{Background information}

The South African Traditional Belief Scale was originally devised by Schwär (2001) for the purposes of his doctoral study. This instrument measures the extent to which black South Africans adhere to traditional beliefs and customs. A culturally traditional person adheres firmly to traditional beliefs, customs, ceremonies and rituals, whereas a westernised person has lost touch with traditional African beliefs. In this regard a high score indicates that a person holds strongly to conventional African beliefs, whereas a low score indicates that an individual is westernised. An intermediary score, on the other hand, indicates that the participant is acculturated, which would imply that the traditional African way of life is to some extent influenced by western culture (Schwär, 2001:158-161).

Although Edwards and his colleagues (Edwards, Grobbelaar, Nene, Makunga, Kunene \& Sibaya, 1985:15-16) compiled a similar scale measuring traditional beliefs and traditions (Degree of Enculturation Survey -DES), the SATBS was developed for several reasons. The DES was firstly developed to measure the cultural beliefs of students at the University of Zululand and is therefore suitable for educated participants only. The language used in many of the items is therefore complicated and would not be comprehensible to the broader population. The DES furthermore covers a limited scope of cultural beliefs and consists only of 20 items. In order to ensure greater validity, the SATBS was compiled, covering a broader range of cultural beliefs, contained in a larger sample of items. The DES also requires simple yes or no answers which might predispose response bias (yea-saying or naysaying). Lastly, although the DES provides research evidence of construct validity, it has no reliability data. 
In order to develop original items for the SATBS, Schwär (2001:83-129) conducted an extensive review of the literature regarding the beliefs, customs and traditions of Southern African indigenous people. From this literature survey he identified beliefs and customs and described eight key cultural areas. These included family and kinship relations, ancestors, witchcraft and sorcery, beliefs concerning health and the causes of illness and misfortune, traditional healers, and lastly rituals. Beliefs about rituals included three important lifecycle events of birth, marriage and death. The most widespread beliefs and customs were then formulated as questionnaire items which constituted the initial questionnaire. All questions in the SATBS relate specifically to both Nguni and Sotho cultures. The SATBS is therefore applicable to the cultural beliefs and customs of the majority of black South Africans (for example, Zulu, Xhosa, Swazi, Ndebele, Pedi, Tswana and Southern Sotho groups).

The initial questionnaire consisted of 58 questions, but after the item analysis, the final questionnaire consisted of 41 items. Table 1 illustrates the number of items covering each category, before and after the item analysis. The number of items in each category was based on the amount of beliefs and customs reported in the literature survey (Schwär, 2001:158-161).

The questions focus on specific beliefs and these are stated in terms of observable behaviours. Special care was taken to keep the language as unambiguous as possible. Key terms were expressed in African languages, in order to make the questionnaire easy to answer. Traditional ceremonies and rituals were phrased in Nguni and Sotho terminology.

\section{Answering, scoring and interpretation of the SATBS}

The SATBS is a self-report inventory, which can be completed by both literate and illiterate persons. In the case of illiteracy, the clinician can read the questions and tick the appropriate answers on behalf of the participant.

The SATBS measures on a 3-point Likert scale. Possible responses are either: "agree, partially agree and disagree", or "always, sometimes and never". The sequence of these responses was varied in different directions, to prevent response bias.

The SATBS is scored by adding the numerical values

Table 1: Categories of beliefs and customs with their number of items before and after item analysis

\begin{tabular}{|c|c|c|}
\hline Belief category & $\begin{array}{l}\text { Number of items before item } \\
\text { analysis }\end{array}$ & $\begin{array}{l}\text { Number of items after item } \\
\text { analysis }\end{array}$ \\
\hline $\begin{array}{l}\text { Family and kinship beliefs and } \\
\text { customs }\end{array}$ & 7 & 4 \\
\hline $\begin{array}{l}\text { Beliefs and customs concerning } \\
\text { ancestors }\end{array}$ & 8 & 8 \\
\hline $\begin{array}{l}\text { Beliefs concerning witchcraft and } \\
\text { sorcery }\end{array}$ & 12 & 6 \\
\hline $\begin{array}{l}\text { Beliefs about health and the causes } \\
\text { of illness and misfortune }\end{array}$ & 7 & 6 \\
\hline $\begin{array}{l}\text { Beliefs and customs concerning } \\
\text { traditional healers }\end{array}$ & 6 & 5 \\
\hline $\begin{array}{l}\text { Beliefs and customs about rituals } \\
\text { concerning childbirth }\end{array}$ & 10 & 6 \\
\hline $\begin{array}{l}\text { Beliefs and customs concerning } \\
\text { marriage }\end{array}$ & 5 & 4 \\
\hline $\begin{array}{l}\text { Beliefs and customs about death } \\
\text { rituals }\end{array}$ & 3 & 2 \\
\hline Total: & 58 & 41 \\
\hline
\end{tabular}


of the indicated answer boxes of each item (see Appendix 1). The maximum obtainable score is 82 and the minimum is 0 . The closer a participant is to the maximum score, the more the person adheres to traditional African beliefs and customs. Individuals scoring in the middle third range (close to 41), on the other hand, partially hold traditional beliefs and customs, but are also influenced by western culture (acculturated). A person scoring close to 0 has lost touch with African traditions and could be considered to be more western (deculturated). The SATBS therefore measures cultural beliefs and customs on a continuum, and can indicate whether a person is traditional, acculturated or westernised. Measuring on a continuum obviates the problem of classifying people into rigid stereotyped categories.

\section{RESEARCH METHODS, STATISTICAL ANALYSIS, SAMPLING AND ETHICAL CONSIDERATIONS}

\section{Research methods}

To establish reliability, an item analysis of the SATBS was conducted, which yielded not only item-total correlations, but also a Chronbach alpha coefficient of internal consistency. This method was deemed appropriate as this questionnaire deals with the homogenous attribute of cultural beliefs.

Criterion validity was established by correlating the SATBS scores with criterion scores obtained from the Degree of Enculturation Survey (DES). The DES was chosen as a yardstick, because it deals with similar content, albeit on a more limited scale. To indicate construct validity of the DES, Edwards et al. (1985:69) conducted a study to establish the conception of mental illness of samples of university students. Sample A consisted of younger (average age $=22.9 ; n=36$ ) urban students, whereas sample $\mathrm{C}$ contained older students (average age $=38.7 ; n=71$ ) from rural backgrounds. If the DES has construct validity, one would expect that the majority of sample $C$ would attribute the causes of mental illness to traditional beliefs, whereas the younger, more urbanised subjects of sample A would attribute aetiology to bio-psycho-social factors. This hypothesis was indeed accepted, as $62 \%$ of participants in sample $\mathrm{C}$ ascribed mental illness to traditional African causes where $77 \%$ of sample A con- tributed the causes either to western theories (deculturation), or to a mixture of African and western beliefs (acculturation). A chi square analysis furthermore indicated that there was a significant difference between the sample groups $\left(\div^{2}=19.88, p<0.001\right)$. These results indicate that the DES has construct validity, as it clearly differentiates between the cultural beliefs of younger urban participants who are more westernised in their beliefs, whereas older rural subjects hold more pure traditional African beliefs.

\section{Statistical analysis}

The SPSS for Windows version 9.0 was used to conduct the item analysis in the case of the reliability study and the Spearman Rank Order Correlation employed to obtain criterion validity.

\section{Sampling procedure}

To establish reliability and validity a sample of $64 \mathrm{sec}-$ ond-year students were randomly selected from Vista University (East Rand Campus). The authors decided to employ university students, because the criterion questionnaire (DES) uses language that might be incomprehensible to uneducated participants. (It is, however, important to note that special care was taken in the phrasing of the SATBS for it to be understandable to a much broader range of the population).

Initially a sampling frame of 257 second-year students was drawn. Each student was then assigned a number from 1 to 257. By using the Corel Quattro Pro 8 random number generator, 100 students were selected and invited to attend the assessment session. Eventually 73 arrived for the measurement sitting, but only 64 belonged to the Nguni and Sotho cultural categories.

The biographical information of the sample group was analysed and yielded the following information. A small majority (56.25\%) of the participants were of Nguni origin $(n=36)$, whereas $43.75 \%(n=28)$ were Sotho-speaking. Questionnaire results revealed that $35.94 \%(n=23)$ of the sample held traditional African beliefs, while $17.19 \%$ reported acculturated beliefs $(n=11)$, and $46.88 \%$ showed deculturated $(n=30)$ beliefs. The mean age of the sample was 24.06 ( $\mathrm{sd}=5.86$ ), and $56.25 \%$ ( $\mathrm{n}$ $=36)$ were female and $43.75 \%(n=28)$ were male. 


\section{Ethical considerations}

All participants gave informed consent to participate in the assessment. Confidentiality and anonymity was also guaranteed. Participants were also told that they were free to terminate participation at any given point.

\section{Technical data concerning reliability and validity}

\section{Reliability}

The reliability of the SATBS was established by conducting an item analysis, which yielded an index of internal consistency. A reliability coefficient of 0.91 (Cronbach alpha) was obtained after the first iteration. After this iteration, 17 items with low item-total correlations (numbers 4, 8, 13, 16, 17, 20, 21, 28, 30, 33, 37, $38,42,44,46,50$ and 51) were omitted from the original questionnaire. As a result of this first iteration, the reliability coefficient rose to 0.9307 . Further iterations failed to yield a higher index of internal consistency. Due to the very high reliability coefficient obtained after the first iteration, the final version of the scale consisting of 41 items was then accepted (see Appendix 1).
Table 2 presents the item analysis where each item was correlated with the test-total score. Items indicated with an asterisk had low correlations and were accordingly omitted from the final questionnaire.

\section{Validity}

In order to establish criterion validity, the SATBS was validated against the DES by using the same random sample of 64 second-year students at Vista University (East Rand campus). They were asked to complete the SATBS as well as the DES. The scores of these questionnaires were then correlated by means of the Spearman Rank Order Correlation. A validity coefficient of 0.7899 was obtained which indicates a high index of criterion validity. The questionnaire therefore measures an attribute similar to that of the DES, and therefore assesses what it purports to measure.

\section{USING THE SATBS TO PROMOTE CUL- TURE-CONGRUENT CARE}

The SATBS could be a useful instrument to identify cases requiring culture-congruent medical or psycho-

Table 2: Item analysis: SATBS

\begin{tabular}{|l|l|l|l|l|l|}
\hline Item number & Cronbach alpha & Item number & Cronbach alpha & Item number & Cronbach alpha \\
\hline 1 & 0.4611 & 21 & $0.0597^{*}$ & 41 & 0.5578 \\
\hline 2 & 0.4246 & 22 & 0.3711 & 42 & $0.2629^{*}$ \\
\hline 3 & 0.5937 & 23 & 0.3583 & 43 & 0.3310 \\
\hline 4 & $0.2699^{*}$ & 24 & 0.3882 & 44 & $0.2619^{*}$ \\
\hline 5 & 0.5525 & 25 & 0.5457 & 45 & 0.6463 \\
\hline 6 & 0.6765 & 26 & 0.3732 & 46 & $0.0195^{*}$ \\
\hline 7 & 0.5992 & 27 & 0.6674 & 47 & 0.3820 \\
\hline 8 & $0.1111^{*}$ & 28 & $0.1264^{*}$ & 48 & 0.5171 \\
\hline 9 & 0.6223 & 29 & 0.4095 & 49 & 0.5766 \\
\hline 10 & 0.3851 & 30 & $0.1605^{*}$ & 50 & $0.0836^{*}$ \\
\hline 11 & 0.5583 & 31 & 0.5225 & 51 & $0.1352^{*}$ \\
\hline 12 & 0.4839 & 32 & 0.4144 & 52 & 0.4533 \\
\hline 13 & $0.1790^{*}$ & 33 & $0.0808^{*}$ & 53 & 0.4305 \\
\hline 14 & 0.4586 & 34 & 0.5943 & 54 & 0.5447 \\
\hline 15 & 0.5143 & 35 & 0.3278 & 55 & 0.5408 \\
\hline 16 & $0.1093^{*}$ & 36 & 0.3000 & 56 & 0.4478 \\
\hline 17 & $0.2498^{*}$ & 37 & $0.1118^{*}$ & 57 & 0.5773 \\
\hline 18 & 0.4818 & 38 & $0.0979^{*}$ & 58 & 0.3109 \\
\hline 19 & 0.4053 & 39 & 0.3180 & & \\
\hline 20 & $0.2418^{*}$ & 40 & 0.5514 & & \\
\hline $\mathrm{N}=64$ & & & & \\
\hline Items omitted after first iteration & & & & \\
\hline
\end{tabular}


logical care. The SATBS can be administered to patients suffering from chronic conditions necessitating long-term compliance to treatment. A participant obtaining a score between 55 and 82 holds traditional African beliefs and would require culture sensitive care. In such a case a care-worker who is familiar with the patient's cultural beliefs should counsel the patient. The care-worker should firstly explain the condition and the importance of treatment compliance in a way that the patient can understand. Secondly he or she should ascertain whether the patient has cultural beliefs or customs that might interfere with the treatment plan. By means of cultural negotiation and compromise the care-worker and patient should then agree on a treatment strategy that is at the same time medically or psychologically appropriate, and also culturally acceptable. This will then ensure greater co-operation from the patient and better treatment outcomes.

\section{CRITICAL EVALUATION OF THE SATBS AND RECOMMENDATIONS FOR FUR- THER DEVELOPMENT AND RESEARCH}

The SATBS could be a useful instrument to identify traditional African patients who require culture-congruent care. Administering the questionnaire is not time consuming, as it can be completed in a few minutes. In the case of illiterate persons, the questions can be read and a care-worker can record the answers.

Although key terms of the SATBS are expressed in Nguni and Sotho languages, the rest of the questionnaire is in English. This is a disadvantage for participants who are not fluent in English. In future the questionnaire could be translated into the major Nguni and Sotho languages, which will make it more accessible to the majority of South Africans.

Although the SATBS only caters for Nguni- and Sothospeaking participants, it does include the vast majority of South African black people. The only cultural groups that are not included are Venda and Tsonga speakers.

The sample used to obtain the reliability and validity data is, however, relatively small and the participants were from a literate and educated background. The authors therefore recommend that future researchers could draw a larger and more representative sample in order to obtain further information on the reliability and validity of the SATBS. Further validity studies can also focus on whether the SATBS differentiates between predetermined traditional, acculturated and deculturated groups.

The SATBS furthermore holds promise for research in the field of cross-cultural health practice and in psychology. The reliability and validity figures are sufficiently high to make the instrument usable for empirical research purposes.

In conclusion the authors express the hope that the SATBS will make a positive contribution to the endeavor of culture-congruent care in South Africa, and that it will become widely used in the medical and psychological care professions.

\section{REFERENCES}

BENJAMIN BJ, \& SPACEK, S 2001: Multicultural issues in health care. Journal of Multicultural Nursing and Health, 7(3):1-5. CUBRIA, K 2001: A sympathetic ear. Pharmaceutical Executive, $21(3): 1$.

CULHANE-PERA, K 2001: Commentary: What listening to patients can teach us. Western Journal of Medicine, 175(5):1.

DAVIDHIZAR, R \& GIGER, JN 2001: Teaching culture within the nursing curriculum using the Giger-Davidhizar model of transcultural nursing assessment. Journal of Nursing Education, 40(6):1-3.

DE VILLIERS, L \& HERSELMAN, S 2004: Meta-theoretical and theoretical perspectives on cultural studies. (In: Tjale, AA \& De Villiers, L eds 2004: Cultural Issues in health and health care. Cape Town: Juta Academic, pp 12-29.)

EDWARDS, SD 1985: Some indigenous South African views on illness and healing. (In: Edwards, SD; Grobbelaar, PW; Nene, LM; Makunga, NV; Kunene, ST \& Sibaya, PT eds 1985: Reaction to illness and concepts of mental illness among representative samples of rural, urban and university educated Black people. KwaDlangezwa: University of Zululand).

FOLEY, R \& WURMSER, TA 2004: Culture diversity: A mobile workforce command creative leadership, new partnerships, and innovative approaches to integration. Nursing Administration Quarterly, 28(2):1-7.

GREEN-HERNADEZ, C; QUINN, AA; DENMAN-VITALE, S; FALKENSTERN, SK \& JUDGE-ELLIS, T 2004: Making nursing care culturally competent. Holistic Nursing Practice, 18(4):1-4. HERSELMAN, S 2004: The anthropology of health. (In: Tjale, AA \& De Villiers, L eds 2004: Cultural Issues in Health and Health Care. Cape Town: Juta Academic, pp 134-158). 
HICKSON, J \& CHRISTIE, GH 1989: Research on cross-cultural counseling and psychotherapy: Implications for the South African context. South African Journal of Psychology, 19(30):162171.

MAURDANT, A 2003: Risky sexual behaviour amongst South African teenagers and the role of HIV/AIDS educational programmes. Johannesburg: Rand Afrikaans University (MA mini-dissertation). MCEWEN, M 2004: Analysis of spirituality content in nursing textbooks. Journal of Nursing Education, 43(1):1-13.

MKIZE, DL 2003: Towards an Afrocentric approach to psychiatry. South African Journal of Psychiatry, 9(1):3-6.

MOKHOSI, MT \& GRIEVE, KW 2004: African families' perceptions of traumatic brain injury. South African Journal of Psychology, 34(2):301-317.

NARAYANASAMY, A 2003: Transcultural nursing: How do nurses respond to cultural needs? British Journal of Nursing, 12(3):113.

SCHWÄR, GH 2001: The relationship between spiritual belief, religious orientation and existential meaning. Pretoria: Vista University. (Unpublished doctoral thesis).

TJALE, AA 2004: Historical perspective. (In: Tjale, AA \& De Villiers, L eds 2004: Cultural Issues in Health and Health Care. Cape Town: Juta Academic, pp 1-11).

WADE, P \& BERNSTEIN, BL 1991: Culture sensitivity training and counsellor's race: Effects on black female clients' perceptions and attrition. Journal of Counselling Psychology, 38(1):9-15. 


\section{APPENDIX: THE FINAL SOUTH AFRICAN TRADITIONAL BELIEF SCALE (SATBS) (41 ITEMS)}

\section{INSTRUCTIONS}

A number of statements concerning certain beliefs you hold and some behaviours you may engage in, are given below. Read each statement and mark ONE of the choices under the statement to indicate your choice.

Please answer all the questions as truly as you can. This is not a test of ability, and there are no right or wrong answers. Try to choose the answer that most clearly describes what you believe or do, rather than the answer you think you should choose or would like to be true.

1. A year after the death of a family member, we celebrate the ukubuyisa idlozi/ukuguqula ceremony

\begin{tabular}{|l|l|l|}
\hline Never (0) & Sometimes (1) & Always (2) \\
\hline
\end{tabular}

2. Witches can fly faster than the speed of sound

\begin{tabular}{|l|l|l|}
\hline Agree (2) & Partially agree (1) & Disagree (0) \\
\hline
\end{tabular}

3. When anything goes wrong in my life, I consult an isangoma/selaoli

\begin{tabular}{|l|l|l|}
\hline Never (0) & Sometimes (1) & Always (2) \\
\hline
\end{tabular}

4. The amadlozi/badimo send me misfortune if I did not bring them my offerings of food

\begin{tabular}{|l|l|l|}
\hline Never (0) & Sometimes (1) & Always (2) \\
\hline
\end{tabular}

5. The amadlozi/badimo have to be cared for like human beings

\begin{tabular}{|l|l|l|}
\hline Agree (2) & Partially agree (1) & Disagree (0) \\
\hline
\end{tabular}

6. After the birth of an eldest child there should be a feast which includes either brewing beer or slaughtering an animal

\begin{tabular}{|l|l|l|}
\hline Disagree (0) & Partially agree (1) & Agree (2) \\
\hline
\end{tabular}

7. An isangoma/selaoli helps me ward off the ill-effects of the abathakathi/baloi

\begin{tabular}{|l|l|l|}
\hline Agree (2) & Partially agree (1) & Disagree (0) \\
\hline
\end{tabular}

8. When a young man gets married, he should pay lobola

\begin{tabular}{|l|l|l|}
\hline Disagree (0) & Partially agree (1) & Agree (2) \\
\hline
\end{tabular}

9. The amadlozi/badimo have to receive offerings and sacrifices from their human family when a child is born

\begin{tabular}{|l|l|l|}
\hline Agree (2) & Partially agree (1) & Disagree (0) \\
\hline
\end{tabular}

10. I have personally taken part in a confession ceremony

\begin{tabular}{|l|l|l|}
\hline Never (0) & Sometimes (1) & Always (2) \\
\hline
\end{tabular}

11. A new-born child should be held in the smoke of a fire

\begin{tabular}{|l|l|l|}
\hline Agree (2) & Partially agree (1) & Disagree (0) \\
\hline
\end{tabular}

12. If a person shows the signs of ukuthwasa, and the amadlozi/badimo are calling him to become an isangoma/selaoli, he is not allowed to refuse the calling

\begin{tabular}{|l|l|l|}
\hline Disagree (0) & Partially agree (1) & Agree (2) \\
\hline
\end{tabular}


13. A marriage is only complete once a child has been born

\begin{tabular}{|l|l}
\hline Disagree $(0)$ & Partially agree (1)
\end{tabular}

\begin{tabular}{|l|l|}
\hline Disagree (0) & Partially agree (1) \\
\hline
\end{tabular}

Agree (2)

14. Witches can enter houses through cracks in doors or walls

\begin{tabular}{|l|l|l|}
\hline Agree (2) & Partially agree (1) & Disagree (0) \\
\hline
\end{tabular}

15. Women should wear special dolls when they cannot have children

\begin{tabular}{|l|l|l|}
\hline Agree (2) & Partially agree (1) & Disagree (0) \\
\hline
\end{tabular}

16. When I meet a stranger who speaks my home language, my first duty is to find out whether and how we are related

\begin{tabular}{|l|l|l|}
\hline Always (2) & Sometimes (1) & Never (0) \\
\hline
\end{tabular}

17. It is the duty of the eldest son to take the lead in the funeral ceremony for his deceased parents

\begin{tabular}{|l|l|l|}
\hline Disagree (0) & Partially agree (1) & Agree (2) \\
\hline
\end{tabular}

18. If beer is not offered to the amadlozi/badimo when we are brewing, they will punish us

\begin{tabular}{|l|l|l|}
\hline Agree (2) & Partially agree (1) & Disagree (0) \\
\hline
\end{tabular}

19. At the birth of a child medicine should be given to the mother and the child

\begin{tabular}{|l|l|l|}
\hline Agree (2) & Partially agree (1) & Disagree (0) \\
\hline
\end{tabular}

20. My family and I regularly bring sacrifices and offerings to the amadlozi/badimo

\begin{tabular}{|l|l|l|}
\hline Never (0) & Sometimes (1) & Always (2) \\
\hline
\end{tabular}

21. If a woman cannot enjoy sexual intercourse, I blame it on the thikoloshe

\begin{tabular}{|l|l|l|}
\hline Disagree (0) & Partially agree (1) & Agree (2) \\
\hline
\end{tabular}

22. In the past I have consulted an isangoma/selaoli regarding some personal matter like my relationship with family members

\begin{tabular}{|l|l|l|}
\hline Never $(0)$ & Sometimes (1) & Always (2) \\
\hline
\end{tabular}

23. The opinion of my father is more important to me than my own concerning big decisions like marrying or moving away from home

\begin{tabular}{|l|l|l|}
\hline Never (0) & Sometimes (1) & Always (2) \\
\hline
\end{tabular}

24. I consult an isangoma/selaoli when a Western doctor cannot heal me

\begin{tabular}{|l|l|l|}
\hline Never (0) & Sometimes (1) & Always (2) \\
\hline
\end{tabular}

25. After the birth of a child the afterbirth should be buried

\begin{tabular}{|l|l|l|}
\hline Disagree (0) & Partially agree (1) & Agree (2) \\
\hline
\end{tabular}

26. At funerals either a goat or a cow are slaughtered

\begin{tabular}{|l|l|l|}
\hline Never (0) & Sometimes (1) & Always (2) \\
\hline
\end{tabular}

27. The amadlozi/badimo live in an invisible world which is very much the same as ours 


\begin{tabular}{|l|l|l|}
\hline Agree (2) & Partially agree (1) Disagree (0) \\
\hline
\end{tabular}

28. When my family fails to observe ukubuyisa/guqula, the amadlozi/badimo will send us misfortune

\begin{tabular}{|l|l|l|}
\hline Never $(0)$ & Sometimes (1) & Always (2) \\
\hline
\end{tabular}

29. An isangoma/selaoli can help me to avert the evil of the abathakathi/baloi

\begin{tabular}{|l|l|l|}
\hline Agree (2) & Partially agree (1) & Disagree (0) \\
\hline
\end{tabular}

30.I wear lucky charms to protect me from the abathakathi/baloi

\begin{tabular}{|l|l|l|}
\hline Never (0) & Sometimes (1) & Always (2) \\
\hline
\end{tabular}

31. I feel very guilty towards the amadlozi/badimo when misfortune comes my way

\begin{tabular}{|l|l|l|}
\hline Always (2) & Sometimes (1) & Never (0) \\
\hline
\end{tabular}

32. A man may not be present at the birth of his child

\begin{tabular}{|l|l|l|}
\hline Disagree (0) & Partially agree (1) & Agree (2) \\
\hline
\end{tabular}

33. I go to the graves of the amadlozi/badimo with offerings of food and do my prayers there

\begin{tabular}{|l|l|l|}
\hline Always (2) & Sometimes (1) & Never (0) \\
\hline
\end{tabular}

34. The amadlozi/badimo will send me misfortune if I do not respect my father

\begin{tabular}{|l|l|l|}
\hline Always (2) & Sometimes (1) & Never (0) \\
\hline
\end{tabular}

35. A deceased person becomes a spirit but stays part of the human family

\begin{tabular}{|l|l|l|}
\hline Agree (2) & Partially agree (1) & Disagree (0) \\
\hline
\end{tabular}

36. At marriage ceremonies cows or goats should be slaughtered

\begin{tabular}{|l|l|l|}
\hline Disagree (0) & Partially agree (1) & Agree (2) \\
\hline
\end{tabular}

37. An isangoma/selaoli is able to tell who causes misfortune in people's lives

\begin{tabular}{|l|l|l|}
\hline Disagree (0) & Partially agree (1) & Agree (2) \\
\hline
\end{tabular}

38. I go to the graves of my amadlozi/badimo and pray there

\begin{tabular}{|l|l|l|}
\hline Always (2) & Sometimes (1) & Never (0) \\
\hline
\end{tabular}

39. Witches cause mental illness

\begin{tabular}{|l|l|l|}
\hline Disagree (0) & Partially agree (1) & Agree (2) \\
\hline
\end{tabular}

40. If I do not inform the amadlozi/badimo of important events in my life, they will punish me

\begin{tabular}{|l|l|l|}
\hline Agree (2) & Partially agree (1) & Disagree (0) \\
\hline
\end{tabular}

41. Witches eat human flesh

\begin{tabular}{|l|l|l|}
\hline Agree (2) & Partially agree (1) & Disagree (0) \\
\hline
\end{tabular}

